\title{
Perkembangan Fisik Dan Body Image Remaja
}

\section{Hartini. M.Pd. Kons \\ Universitas Pendidikan Indonesia Bandung}

\begin{abstract}
Abstrak
Pengkajian tahap perkembangan hendaknya dapat memberikan pemahaman dan informasi yang berguna bagi remaja, orang tua, orang dewasa maupun guru di sekolah. Berbagai perubahan-perubahan yang dialami remaja sering menimbulkan kebingguan dan permasalahan yang dapat mempengaruhi kondisi psikologis remaja dan orang-orang disekitar para remaja sehingga sangat penting para remaja dan orang-orang disekitar remaja mengetahui dan memahami berbagai perubahan yang dialami remaja. Pengetahuan dan pemahaman tentang perkembangan fisik remaja merupakan informasi awal yang sangat penting diketahui karena perubahan fisik yang dialami oleh remaja akan mempengaruhi berbagai perkembangan lainya seperti perkembangan kognitif, moral, sosial, dan religius sehingga kajian tentang perkembangan fisik diharapkan dapat memberikan berbagai informasi dan pemahaman dan akan mengantisipasi serta meminimalis berbagai permasalahan yang akan dihadapi oleh remaja sehingga diperolehnya berbagai problem solving yang dihadapi remaja orang tua, orang dewasa maupun guru di sekolah . Adapun kajian yang akan dibahas dalam perkembangan fisik remaja ini berawal dari penjelasan tentang siapa remaja dilihat dari berbagai aspek, kajian dilanjutkan dengan pembahasan faktor-faktor yang mempengaruhi perkembangan fisik remaja, ciri-ciri remaja, proses perkembangan fisik remaja, dampak psikologis terhadap perubahan fisik remaja serta kendala apa saja yang dialami dalam proses perubahan fisik remaja serta body image remaja dan perilakunya.
\end{abstract}

\section{PENGANTAR}

Masa remaja adalah masa yang paling banyak mengalami perubahan secara psikologis, biologis dan fisiologis. Kondisi ini terjadi melalui berbagai transisi dari berbagai dimensi yang dalam proses perkembanganya mengalami perubahan-perubahan yang berdampak pada munculnya kondisi yang membinggungkan, keragu-raguan, ketakutanketakutan dan kecemasan-kecemasan. Berbagai perubahan ini ada yang dapat dilalui oleh remaja dengan baik dan ada juga sebagain remaja yang mengalami hambatan dan 
gangguan dalam proses perkembangannya sehingga dapat menghambat pencapaian tugas perkembangan selanjutnya.

Pengkajian tahap perkembangan hendaknya dapat memberikan pemahaman dan informasi yang berguna bagi remaja, orang tua, orang dewasa maupun guru di sekolah. Berbagai perubahan-perubahan yang dialami remaja sering menimbulkan kebingguan dan permasalahan yang dapat mempengaruhi kondisi psikologis remaja dan orang-orang disekitar para remaja sehingga sangat penting para remaja dan orang-orang disekitar remaja mengetahui dan memahami berbagai perubahan yang dialami remaja. Pengetahuan dan pemahaman tentang perkembangan fisik remaja merupakan informasi awal yang sangat penting diketahui karena perubahan fisik yang dialami oleh remaja akan mempengaruhi berbagai perkembangan lainya seperti perkembangan kognitif, moral, sosial, dan religius sehingga kajian tentang perkembangan fisik diharapkan dapat memberikan berbagai informasi dan pemahaman dan akan mengantisipasi serta meminimalis berbagai permasalahan yang akan dihadapi oleh remaja sehingga diperolehnya berbagai problem solving yang dihadapi remaja orang tua, orang dewasa maupun guru di sekolah. Adapun kajian yang akan dibahas dalam perkembangan fisik remaja ini berawal dari penjelasan tentang siapa remaja dilihat dari berbagai aspek, kajian dilanjutkan dengan pembahasan faktor-faktor yang mempengaruhi perkembangan fisik remaja, ciri-ciri remaja, proses perkembangan fisik remaja, dampak psikologis terhadap perubahan fisik remaja serta kendala apa saja yang dialami dalam proses perubahan fisik remaja serta body image remaja dan perilakunya.

\section{DEFINISI REMAJA}

Adolescence atau remaja berasal dari bahasa latin adolescere yang berarti 'tumbuh' atau "tumbuh menjadi dewasa". Bangsa primitive pada zaman purbakala mengatakan bahwa masa remaja atau masa puber tidak ada bedanya dengan masa-masa lain dalam rentang kehidupan, anak dianggap dewasa apabila sudah mampu mengadakan reproduksi (Elizabeth B Hurlock. 1991). ${ }^{1}$ Istilah adolenscence seperti yang dipergunakan saat ini, mempunyai arti yang lebih luas mencakup kematangan mental, emosional, sosial dan fisik. Pandangan ini diungkap oleh Piaget dengan menyatakan bahwa :

"Secara Psikologis, masa remaja adalah usia dimana individu berintegrasi dengan masyarakat dewasa, usia dimana anak-anak tidak lagi merasa di bawah tingkatan orang-orang yang lebih tua melainkan berada dalam tingkatan yang sama, sekurang-kurangnya dalam masalah bak.... Integrasi dalam masyarakat

\footnotetext{
${ }^{1}$ Elizabeth B Hurlock. 1980. Developmental Psychology. A life-span approach, fifth edition. McGraw-Hill. Inc. pp. 206 
(dewasa) mempunyai banyak aspek efektif, kurang lebih berhubungan dengan masa puber" (Piaget, J.1969)

Masa puber yang dialami remaja atau masa puberitas merupakan suatu periode kedewasaan kerangka tubuh dan seksual yang cepat, terutama terjadi pada awal remaja merupakan suatu periode dimana kematangan kerangka seksual terjadi secara pesat terutama pada awal remaja.(Santrock John W.1983) ${ }^{3}$ Masa Pubertas juga merupakan masa transisi periode antara masa kanak-kanak dan dewasa, di mana sebuah pertumbuhan Semburan terjadi, karakteristik seksual sekunder muncul kesuburan adalah dicapai, dan perubahan psikologis yang mendalam mengambil Tempat (National Research Council, Board on Children, Youth, and Families. 1999). ${ }^{4}$ dari pertumbuhan, pengembangan, dan pematangan yang dimulai pada akhir dari masa kanak-kanak sekitar 10 tahun. (Neil J. Salkind. 2006) ${ }^{5}$

Pubertas dianggap masa stress yang dialami remaja, Untungnya, selama beberapa dekade terakhir, konsepsi masa remaja sebagai masa badai dan tekanan (Blos, 1962; Hall, 1904) digantikan oleh pandangan yang lebih seimbang bahwa remaja sebagai periode ketika biologis, kognitif, emosional, dan fungsi sosial menjadi direorganisasi. Mayoritas remaja dipandang sebagai individu yang mengalami ketidakmampuan dalam berperilaku yang diinginkan. Periode direorganisasi biologis merupakan periode pertumbuhan dan perkembangan struktur tubuh atau fisik yakni sejak mulai pubertas dan waktu pubertas, terjadi pengaruh yang interaktif antara hormon, pertumbuhan fisik, perubahan emosi, masalah perilaku, kognisi, dan aktivitas seksual. ${ }^{6}$

\section{FAKTOR-FAKTOR PERKEMBANGAN FISIK REMAJA}

Masa remaja dianggap mulai pada saat anak secara seksual menjadi matang dan berakhir saat ia mencapai usia matang secara hukum. Secara umum remaja dibagi menjadi dua bagian yakni awal masa remaja dan akhir masa remaja. Masa remaja dimulai pada usia 13-16 tahun yakni awal masa remaja dan usia 16-17 tahun yakni akhir masa remaja dimana merupakan periode yang sangat singkat. Anak remaja laki-laki lebih lambat matang daripada anak perempuan sehingga remaja laki-laki mengalami

\footnotetext{
${ }^{2}$ (Piaget, J.1969. The Intellectual development of the adolescence: Psychosocial perspectives, New York: Basic Books. p.22-26)

${ }^{3}$ Santrock John W.1983. Life-Span Development : 5 E. University of Texas At Dallas. C. Brown Communication, Inc.) p. 7

${ }^{4}$ National Research Council, Board on Children, Youth, and Families. (1999). Adolescentdevelopment and the biology of puberty.

Washington:National Academy Press. p. 1

${ }^{5}$ Neil J. Salkind. 2006 , Encyclopedia of human development. the United States of America. Sage Publications, Inc. p. 28

${ }^{6}$ Richard M. Lerner, M. Ann Easterbrooks, Jayanthi Mistry. (2003) Handbook Of Psychology. Volume 6 Developmental Psychology. By John Wiley \& Sons, Inc., Hoboken, New Jersey.. 
periode awal remaja yang lebih singkat sehingga sering kali remaja laki-laki nampak kurang matang dibandingkan remaja perempuan. (Elizabeth B. Hurlock, 1991) ${ }^{7}$.

Menurut Neil J. Salkind. $(2006)^{8}$ fase perkembangan fisik remaja diawali saat masa puberitas tiba meliputi awal masa remaja (usia 10-14 tahun), sebagian remaja mulai mengalami lonjakan pertumbuhan fisik dan mulai pematangan seksual yang mengakibatkan terjadinya perubahan yang signifikan di semua domain fungsi. Masa remaja Tengah (usia 14-17 Tahun) Pembangunan fisik Kebanyakan remaja mengalami terus meningkat di spesialisasi keterampilan motorik kasar, massa otot, kekuatan, dan daya tahan cardiopulmonary. beberapa remaja mungkin menemukan kesulitan untuk menyesuaikan diri somatik pertumbuhan menyembur, yang dapat mengakibatkan kejanggalan sementara atau kecanggungan. Beberapa pemuda dapat menjadi sangat prihatin tentang kenaikan normal mereka berat badan dan ukuran. Hal ini dapat mengakibatkan diet yang berlebihan dan olahraga, membersihkan, atau tindakan pengendalian berat badan patogen lainnya. Motor, Visual, dan Pembangunan auditory Semua keterampilan di domain ini sepenuhnya dikembangkan di akhir masa remaja tengah, dengan pengecualian dari menjepit pegang, yang terus berkembang pada akhir masa remaja. Sedangkan Akhir Masa remaja (usia 17-21 tahun) Selama tahap perkembangan, remaja menghadapi lulus SMA, tes penempatan, dan sering kegiatan perguruan tinggi atau pilihan karir. Pada akhir masa remaja akhir, yang paling muda mencapai penuh fisik, kognitif, sosial, dan kematangan emosional, dan sebagian besar masalah emansipasi pada dasarnya diselesaikan. Pembangunan fisik Spesialisasi keterampilan motorik kasar, keuntungan di kekuatan, dan kapasitas aerobik sepenuhnya dikembangkan; Namun, beberapa remaja dapat terus berkembang kecepatan dan peningkatan ukuran; perubahan ini terjadi pada tingkat yang lebih lambat dibandingkan dengan selama masa remaja tengah, dan betina terus menumpuk massa lemak. Mereka Visi sepenuhnya dikembangkan. ${ }^{9}$

Ada beberapa faktor penyebab terjadinya perkembangan fisik pada diri remaja yaitu terjadinya produksi hormon yang sangat banyak yakni zat-zat kimia yang sangat kuat yang disekresikan oleh kelenjar-kelenjar endokrin dan dibawa keseluruh tubuh oleh aliran darah (Dyk, 1993) konsentrasi hormone-hormon tertentu meningkat secara dramatis selama masa remaja (Rabin \& Chrousos, 1991; Susman \& Dorn, 1991). Adapun hormone tersebut yaitu hormon testosteron (testosterone) ialah suatu hormone yang berkaitan dengan perkembangan alat kelamin, pertambahan tinggi dan perubahan

\footnotetext{
${ }_{8}^{7}$ Elizabeth B Hurlock. 1980. Developmental Psychology. A life-span approach, fifth edition. McGraw-Hill. Inc. pp. 206 ${ }^{8}$ Op cit

${ }^{9}$ Op cit, Neil J. Salkind. 2006 P. 34
} 
suara pada anak laki-laki. Sedangkan hormon estradiol ialah suatu hormon yang berkaitan dengan perkembangan buah dada, Rahim, dan kerangka pada anak-anak perempuan. $^{10}$

Perubahan secara fisiologis ditandai oleh 2 komponen. Menurut Counts et al., 1987, dua komponen tersebut yaitu adrenarche dan gonadarche, yang dianggap peristiwa independen dikontrol oleh mekanisme terpisah yakni komponen pertama pubertas, adrenarche (kebangkitan kelenjar adrenal), dimulai antara usia 6 dan 9 tahun. Adrenarche merupakan maturasi dari korteks adrenal yang ditandai dengan peningkatan sekresi androgen adrenal yaitu dehydroepiandrosterone (DHEA), dehydroepiandrosterone sulfat (DHEAS) dan androstenedion meningkat hormonal awal adrenal androgen sekresi terjadi sebelum perubahan fisik eksternal, seperti itu pengembangan rambut kemaluan. Komponen kedua pubertas, gonadarche, adalah reaktivasi yang dari hipotalamus-hipofisis gonadotropin-gonadal ( hasilnya kematangan fisik pengembangan karakteristik seksual primer (Testis dan ovarium) dan karakteristik seksual sekunder Rambut kemaluan, rambut tubuh, dan pertumbuhan genital dan payudara). Itu puncak dari gonadarche dan fungsi reproduksi menarche untuk anak perempuan dan anak laki-laki spermarche untuk. dimulai pada usia 8-10 tahun untuk anak perempuan dan 10-11tahun pada anak laki-laki. ${ }^{11}$ sedangkan menurut suntrock (1983) bahwa perubahan hormonal dan perubahan tubuh pada remaja ini terjadi rata-rata 2 tahun lebih awal pada anak perempuan usia 10,5 tahun dari pada anak laki-laki 12.5 tahun. $^{12}$

\section{CIRI-CIRI PERKEMBANGAN FISIK REMAJA}

Perubahan dan perkembangan fisik pada remaja tidaklah sama dan terdapat perbedaan individual, yakni terjadinya penurunan dalam laju pertumbuhan dan perkembangan internal lebih menonjol daripada perkembangan ekternal yang secara normal akan terjadi disetiap diri remaja. Menurut Santrock $(1983)^{13}$ ada 4 perubahan tubuh yang paling menenjol pada remaja perempuan yakni : Pertambahan tinggi badan yang cepat, Menarche (Menstruasi) ,Pertumbuhan buah dada, Pertumbuhan rambut kemaluan. Sedangkan 4 perubahan yang menonjol pada remaja laki-laki yakni : pertambahan tinggi badan yang cepat, pertumbuhan penis, pertumbuhan testis, pertumbuhan rambut kemaluan.

\footnotetext{
${ }^{10}$ (Santrock John W.1983. Life-Span Development : 5 E. University of Texas At Dallas. C. Brown Communication, Inc.) p. 7

${ }^{11}$ Op cit Richard M. Lerner, M. Ann Easterbrooks, Jayanthi Mistry. p. 298

${ }^{12}$ Op cit , Santrock John Wp. 8

${ }^{13}$ Ibid p. 8
}

ISLAMIC COUNSELING VOL 1 NO. 02 TAHUN 2017, STAIN CURUP 


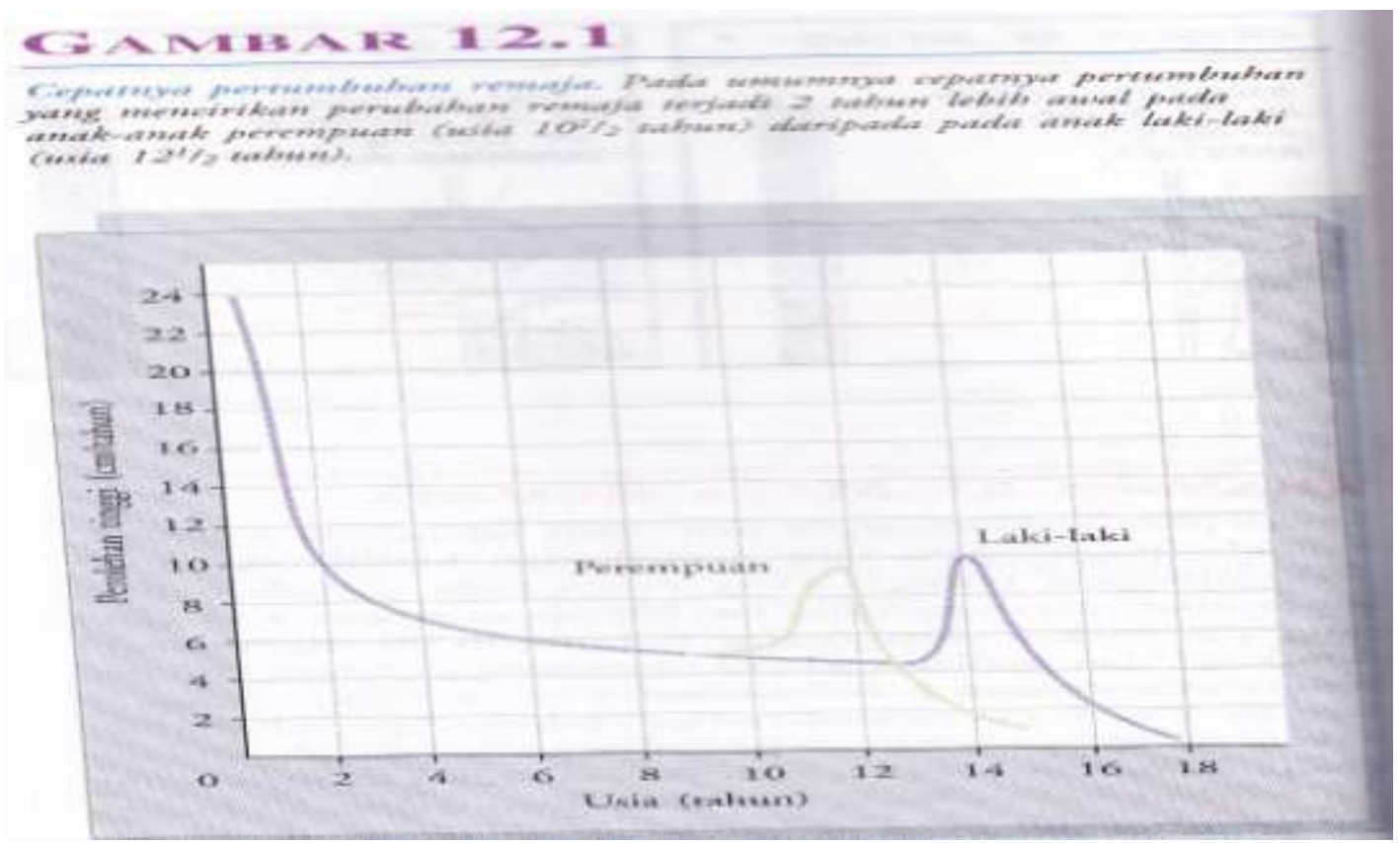

Awal masa puber anak laki-laki, suara mulai menurunkan; kumis mulai tumbuh anak laki-laki, yang melibatkan pematangan organ reproduksi dan menyertainya karakteristik seksual sekunder. Dalam perempuan, menstruasi pertama terjadi pada akhir masa pubertas. Pada akhir pubertas, individu menjadi mampu reproduksi. ${ }^{14}$ (Resource Book. 2005) menurut Elizabeth B Hurlock (1980) mengemukakan bahwa ada 2 aspek perubahan dan perkembangan fisik yang dialami remaja yakni :

\begin{tabular}{|l|l|}
\hline Perubahan Ekternal & Perubahan Internal \\
\hline Tinggi yakni rata-rata perempuan & - Sistem Percernaan, perut menjadi lebih \\
mencapai tinggi yang matang antara & panjang dan tidak lagi terlampau \\
usia 17 dan 18 tahun, rata-rata remaja & berbentuk pipa, bertambah panjang dan \\
laki-laki setahun sesudahnya. Anak & bertambah besar. Otot-otot di perut dan \\
yang biasa diberi imunisasi biasanya & dinding-dinding usus menjadi-1 lebih \\
lebih tinggi dari usia ke usia, & tebal dan lebih kuat, hati bertambah \\
dibandingkan dengan bayi yang tidak & berat dan kerongkongan bertambah \\
diberi imunisasi karena anak banyak & panjang \\
menderita sakit sehingga cendrung & - Sistem Peredaran Darah, yakni jantung \\
memperlambat pertumbuhan & tumbuh pesat selama masa remaja, \\
Berat yakni perubahan berat badan & pada usia tujuh belas atau delapan belas. \\
mengikuti jadwal yang sama dengan & Beratnya dua belas kali berat pada \\
\hline
\end{tabular}

${ }^{14}$ Resource Book. 2005 Child and Adolescent Development. the Pennsylvania Child Welfare Training Program University of Pittsburgh, School of Social Work 403 East Winding Hill Road Mechanicsburg). p.54 


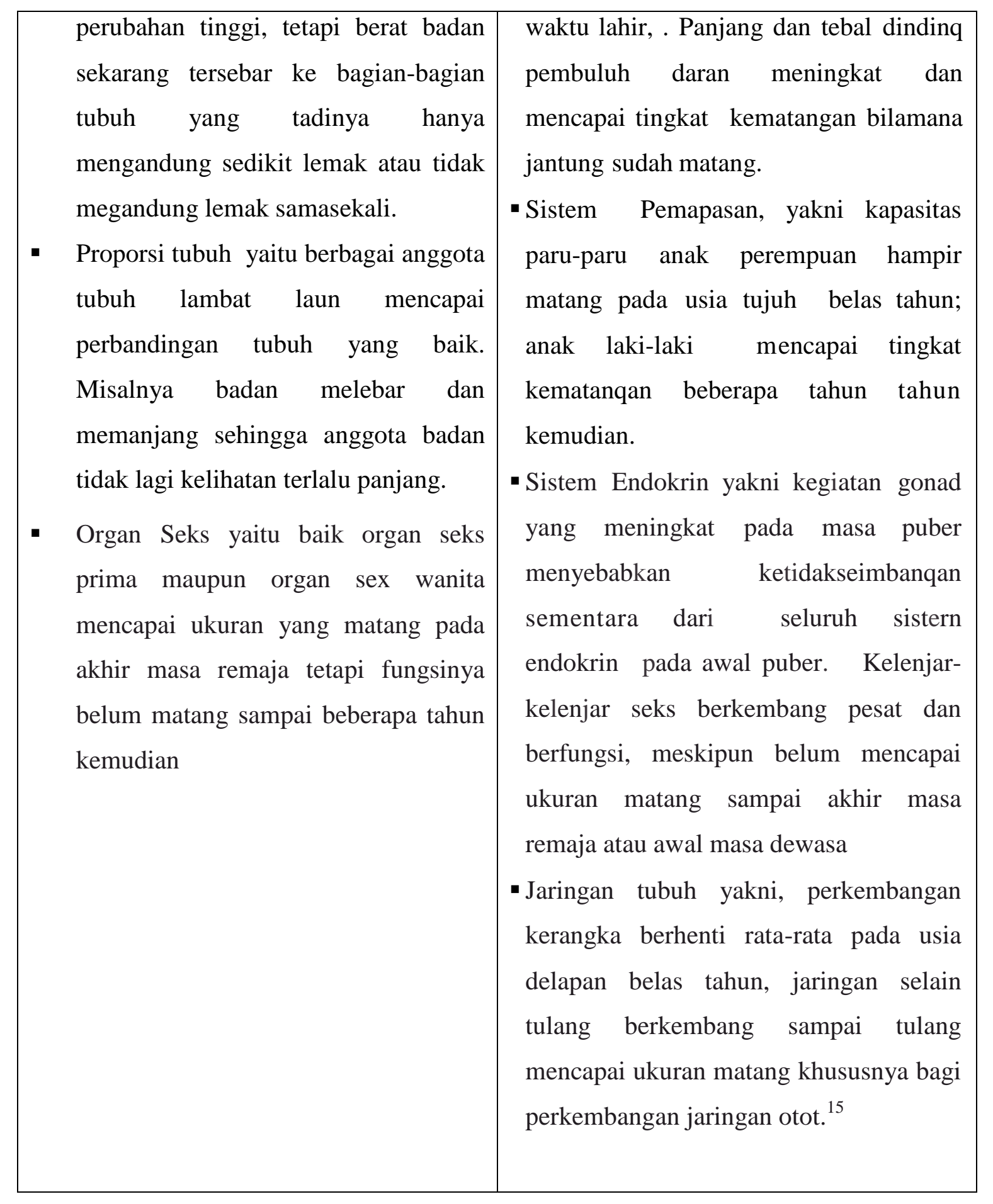

\footnotetext{
${ }^{15}$ Elizabeth B Hurlock. 1980. Developmental Psychology. A life-span approach, fifth edition. McGraw-Hill. Inc. pp. 211 


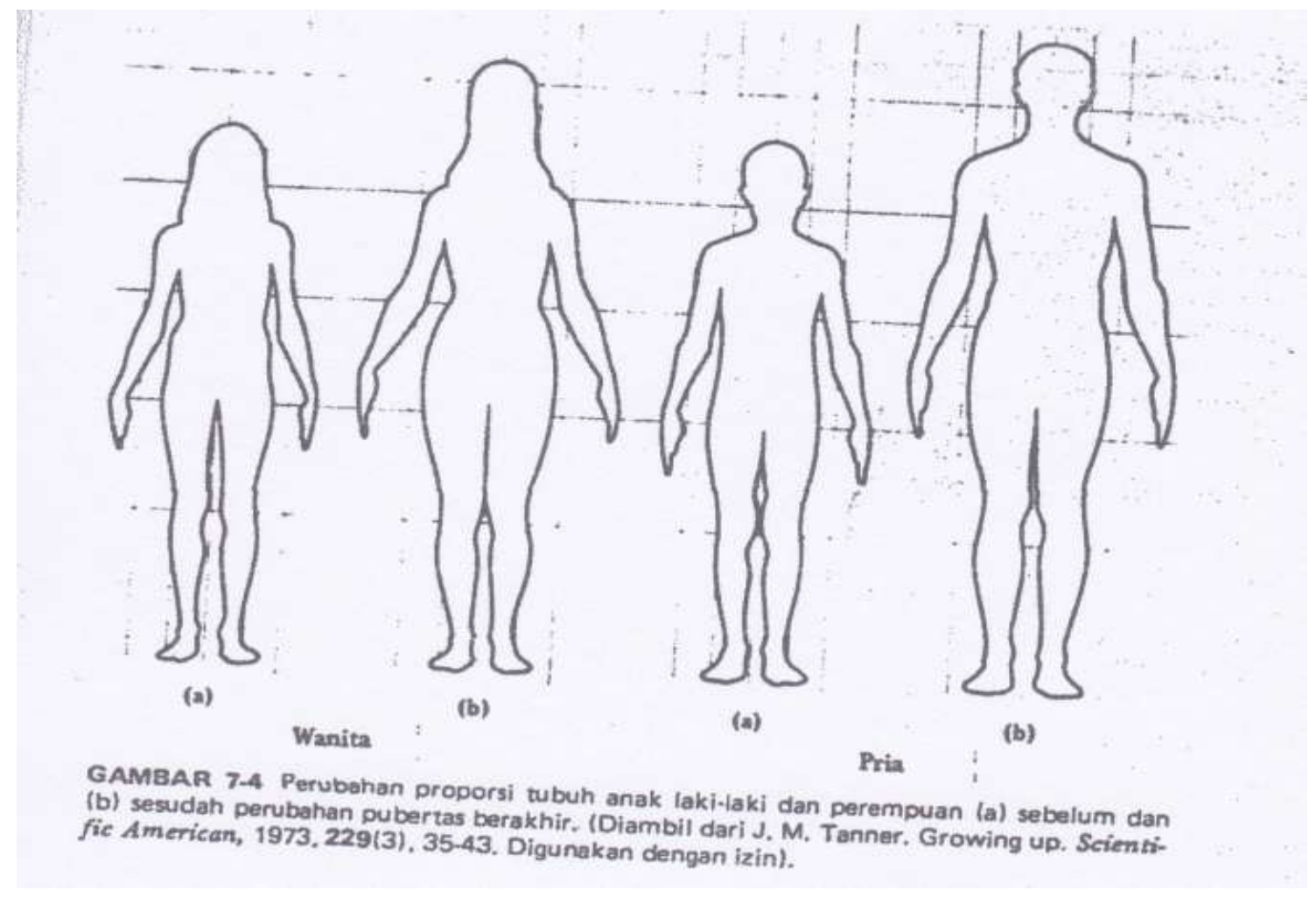

PROSES PERKEMBANGAN FISIK REMAJA

Masa pubertas dapat mulai sejak usia 8 atau akhir usia 15 pada anak perempuan dan sejak usia 9,5 tahun dan hingga akhir usia 15 anak laki-laki. Ini adalah penanda mendefinisikan awal remaja. Akhir masa remaja umumnya terjadi antara usia 17 dan 21 tahun dan ditandai dengan individu mencapai fisik penuh dan jatuh tempo perkembangan atau dewasa muda. Ini fase perkembangan melibatkan fisik yang signifikan, hormonal, kognitif, emosional, dan perubahan sosial. Sebuah perspektif perkembangan saraf remaja menyatakan bahwa sebagian besar perubahan terjadi terjadi pada tiga tumpang tindih tahapan: awal, tengah, dan akhir. awal masa remaja menandai masa pubertas, remaja tengah ditandai dengan pertumbuhan puncak dan pematangan fisik, dan masa remaja akhir menandai akhir dari pubertas dan integrasi semua keterampilan fungsional. (Neil J. Salkind. 2006) ${ }^{16}$

Adapun proses perkembangan fisik merupakan proses berfungsinya dua komponen pubertas yakni, gonadarche, adalah reaktivasi yang dari hipotalamus hipofisis gonadotropin gonadal Sistem, yang awalnya telah diaktifkan selama janin dan perkembangan bayi awal. Gonadarche dimulai sekitar usia 9 sampai 10 tahun pada anak perempuan kulit putih dan 8 sampai 9 tahun pada anak perempuan Afrika Amerika (Herman-Giddens et al., 1997) dan pada 10 sampai 11 tahun anak laki-laki (Grumbach \& Styne, 1992). Gonadarche adalah apa yang kebanyakan orang sebut sebagai 
"pubertas" dan memerlukan kematangan seksual dan kematangan reproduksi. Pada gonadarche, aktivasi HPG-axis dan hasilnya kematangan fisik dalam pengembangan karakteristik seksual primer (Testis dan ovarium) dan karakteristik seksual sekunder (Rambut kemaluan, rambut tubuh, dan pertumbuhan genital dan payudara). Itu puncak dari gonadarche dan fungsi reproduksi menarche untuk anak perempuan dan anak lakilaki spermarche untuk. ${ }^{17}$ pubertas yang (Gonadarche) menandai perkembangan kemampuan reproduksi, fisiologi pubertas menjadi identik dengan bahwa pematangan reproduksi. Gonadarche terjadi ketika GnRH generator denyut (neuron di hipotalamus basal medial) diaktifkan kembali atau reaugmented (Knobil, 1988; Medhamurthy, gay, \& Plant, 1990; Tersawa, Bridson, Nass, Noonan, \& Dierschke, 1984) ${ }^{18}$ dan gonad seks steroid hormon meningkat sekresi. Itu mekanisme untuk pemahaman itu sistem kontrol yang mendefinisikan waktu pubertas dan neurobiologis dasar reaugmentation ini pulsa GnRH generator terus menjadi spekulatif (Plant, 1995; Suter, Pohl, \& Plant, 1998). Banyak dari apa yang kita tahu tentang pubertas didasarkan pada model primata nonmanusia. Pada manusia, penelitian pada masa pubertas jauh lebih sulit membawa di luar karena sering seri pengambilan sampel darah pada malam hari di prapubertas anakanak diperlukan sebagai sekresi pulsatil gonadotropin pertama terjadi pada malam hari. Selain itu, tes yang sangat sensitif yang wajib untuk mendeteksi konsentrasi rendah gonadotropin dan steroid gonad. Demikian, beberapa studi manusia yang tersedia di masa pubertas, dan pada mereka yang ada, sampel ukuran kecil dan tidak mungkin wakil dari umum populasi. ${ }^{19}$

Hormon dan pertumbuhan perubahan pada masa pubertas adalah konsekuensi dari proses neuroendokrin rumit. Pada hari-hari awal penelitian pada komponen endokrin pubertas, penekanannya adalah pada spesifisitas c melepaskan hormon atau spesifik hormon fi c seperti testosteron dan estrogen. Penekanannya saat ini adalah pada saraf (Plant, 1998) dan kontrol genetic pubertas. Secara khusus, para identifikasi gen yang spesifik dan ekspresi gen yang bertanggung jawab untuk onset dan perkembangan pubertas sekarang adalah fokus penelitian. Mengingat kemajuan ini, penjelasan yang paling diterima secara luas dari masa pubertas adalah ekspresi gen mengendalikan GnRH pulsa generator dan reaktivasi sumbu HPG. Selain itu, korteks, sistem limbik, dan

\footnotetext{
${ }^{17}$ Richard M. Lerner, M. Ann Easterbrooks, Jayanthi Mistry. (2003) Handbook Of Psychology. Volume 6 Developmental Psychology. By John Wiley \& Sons, Inc., Hoboken, New Jersey..p. . 298

${ }^{18}$ Terasawa, E., Noonan, J. J., Nass, T. E., \& Loose, M. D. (1984). Posterior hypothalamic lesions advance the onset of puberty in the female rhesus monkey. Endocrinology, 115, 2241-2250.

${ }^{19}$ Op, cit Richard M. Lerner, M. Ann Easterbrooks, Jayanthi Mistry. P 299 
sistem neurotransmitter memodulasi fungsi hipotalamus (Brooks-Gunn c\& Reiter1990) dan dengan demikian pubertas. ${ }^{20}$

Masa puberitas merupakan proses kematangan yang dialami oleh manusia yang ditandai dengan adanya pertumbuhan dan perkembangan biologis dan fisiologis. Menurut John Bancrof dan June Machover Reinisch (1990) ${ }^{21}$ bahwa dalam kematangan manusia aktivitas gonad (ovarium pada wanita dan testis pada pria) adalah kendali dua hormon yang diproduksi oleh hipofisis anterior (Gambar. 1-1). hormon-hormon perangsang folikel ini (FSH) dan hormon lu teinizing ( $\mathrm{LH}$ ) - yang juga biasa disebut sebagai gonadotro pin (untuk review, lihat Steiner \& Cameron, 1989) ${ }^{22}$. Pada wanita dewasa, aktivitas ovarium adalah sifat cyclicin dengan ovulatio terjadi sekitar sebulan sekali. FSH bertindak dalam ovarie yang terutama untuk merangsang pertumbuhan folikel ovarium (struktur ovarium yang berisi perempuan sel germinal, ovum). Oleh minggu ke masing-masing siklus folliclehas tunggal biasanya dipilih dan mulai berkembang pesat mensekresi jumlah berlebihan dari hormon estrogen steroid. Sekitar akhir minggu kedua pada setiap siklus, meningkatnya tingkat estroge bertindak di hipofisis menyebabkan pelepasan lonjakan LH dan FSH. Th gonadotropin surge, pada gilirannya, memicu proses ovulasi di whic yang follicleruptures matang dan melepaskan ovum ke dalam tabung Lopian terdekat fal. Di bawah stimulasi LH, yang pecah follicleundergoes bio chemicaland struktural reorganizationto menjadi korpus luteum. Sel dari korpus luteum mensekresikan estrogen dan progesteron, hormon tha tindakan pada lapisan endometrium rahim untuk siap untuk implantatio dari ovum dibuahi. Jika tidak terjadi pembuahan, korpus luteum regresi setelah sekitar 2 minggu. Penarikan pelabuhan dukungan hormonal pada endometrium pada akhir setiap siklus hamil mengarah $t$ pengelupasan jaringan endometrium (yaitu, menstruasi). fungsi testis pada orang dewasa juga dirangsang oleh LH dan FSH LH bertindak pada sel-sel Leydig dari testis untuk merangsang testosteron produksi pro. Testosteron, bertindak dalam tubulus seminiferus, dalam hubungannya dengan FSH, untuk merangsang spermatogenesis. als testosteron memainkan peran trofik penting dalam merangsang aksesori ducts sebuah kelenjar saluran reproduksi pria, produk yang keluar dari whic sangat penting untuk menjaga integritas fungsional sperma. LH dan FSH produksi dan pelepasan dikendalikan oleh peptida kecil hormon, gonadotropin-releasing hormone (GnRH). GnRH adalah pro diproduksi oleh neuron di hipotalamus (wilayah otak di terletak tidak langsung di atas

\footnotetext{
${ }^{20}$ ibid

${ }^{21}$ John Bancrof dan June Machover Reinisch (1990). Adolesence and puberity. New York Oxford Oxford University Press

${ }^{22}$ Steiner, R. A., \& Cameron, J. L. (1989). Endocrine control of reproduction. In B. Hille, A. Fuchs, R. Steiner, \& A. Scher (Eds.), Textbook of physiology (pp 1289-1342). Philadelphia: Saunders.
} 
hipofisis), akson yang berakhir pada tempat tidur capillar dari eminensia median. GnRH dilepaskan dari terminal akson diangkut ke hipofisis anterior oleh pembuluh darah dari hipotalamus yang sistem portal hypophyseal. neuron GnRH mengirimkan akson ke saya keunggulan kemudian muncul api secara terkoordinasi, mengirimkan pulsa dari GnRH ke hipofisis anterior, dan mengakibatkan rilis berdenyut dari gonadotropin hipofisis. Mekanisme (s) dimana GnRH neurons dirangsang untuk api secara berdenyut terkoordinasi masih belum diketahui saat ini. Frekuensi dan amplitudo berdenyut pergi rilis nadotropin bervariasi tergantung pada kondisi fisiologis, dihasilkan dari perubahan frekuensi rilis GnRH. Misalnya, dalam fase midfollicular dari siklus menstruasi rendah penguat LH terjadi kira-kira sekali setiap 90 menit, sedangkan selama fase midluteal LH dirilis di pulsa besar amplitudo pada frekuensi lambat sekitar sekali setiap 8 jam. produksi dan pelepasan. Hal ini diketahui bahwa sejumlah sistem saraf dalam sistem saraf pusat dapat memodulasi aktivitas neuron $\mathrm{GnRH}$, termasuk sistem saraf yang melepaskan neurotransmit- seperti ters sebagai norepinefrin, serotonin, dan peptida opiat endogen.

Hormon yang diproduksi oleh gonad (yaitu, estrogen dan progesteron pada wanita dan testosteron pada pria) memiliki pengaruh penghambatan pada GnRH aktivitas neuron. steroid gonad juga mengerahkan efek negatif-umpan balik secara langsung pada tingkat hipofisis anterior untuk menekan aktivitas sel-sel yang mensekresi LH dan FSH. Betina memiliki sistem umpan balik positif tambahan dengan yang sangat tinggi tingkat estrogen yang dihasilkan oleh tindakan folikel ovarium matang di hipofisis untuk merangsang pelepasan gelombang LH dan FSH. Proses kematangan ini akan dialami oleh setiap manusia sejak masuk fase remaja. Untuk lebih jelasnya dapat di lihat pada gambar di bawah ini :

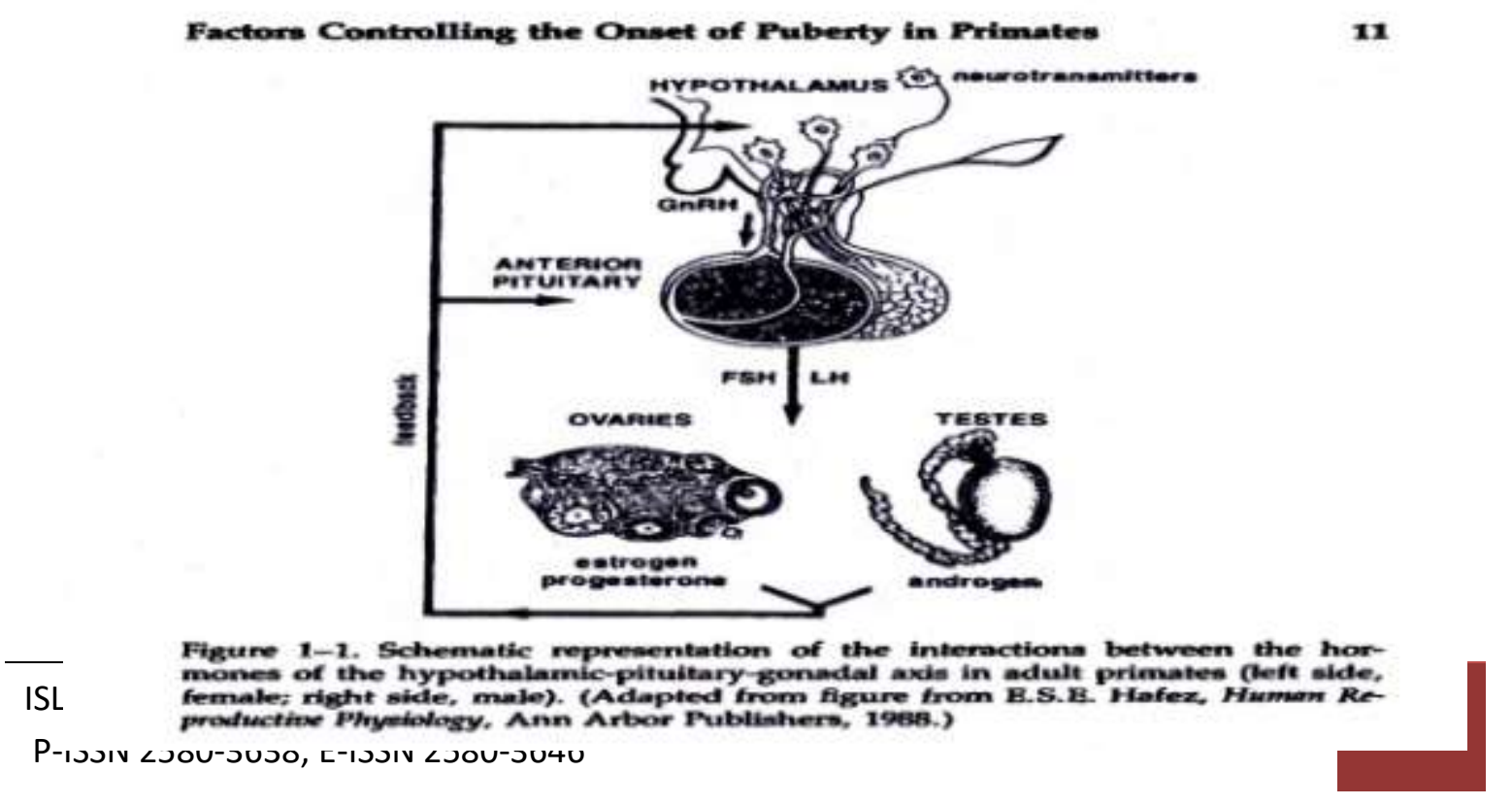


Namun sebuah studi Herman-Giddens et al, $1997^{23}$;. Tentang A study from the Pediatric Research and Office Settings network, diperoleh data bahwa dari 17.000 anak perempuan rentang usia 3-12 tahun yang datang mengunjungi dokter bahwa 6,7\% dari anak perempuan kulit putih dan 27,2\% dari Afrika gadis Amerika yang menunjukkan tanda-tanda pubertas pada usia 7 tahun (yaitu, payudara dan / atau pengembangan rambut kemaluan). Temuan penelitian ini menunjukkan bahwa pubertas mungkin terjadi sekitar 1 tahun awal pada anak perempuan kulit putih dan 2 tahun sebelumnya gadis Afrika di Amerika. Namun, penelitian belum diselesaikan pada sampel nonclinical untuk mengkonfirmasi bahwa ini adalah kasus untuk gadis pada umumnya. Relatif sedikit penelitian telah diperiksa perbedaan dalam perjalanan pubertas antara berbeda kelompok etnis; ini jelas daerah yang layak perhatian tambahan (Lerner \& Galambos, 1998).

Pertumbuhan fisik dan Pembangunan masa pubertas menyebabkan remaja untuk mendapatkan 25\% dari tinggi dewasa akhir nya (hingga $10 \mathrm{~cm}$ per tahun), mendapatkan $50 \%$ dari berat badan orang dewasa yang ideal; pengalaman penggandaan organ utama, pematangan tulang wajah, penurunan jaringan limfoid, genital pematangan, primer dan karakteristik seks sekunder, dan sistem saraf pusat (SSP) pematangan, memicu kenaikan hormon seks termasuk adrenal hormon, estrogen (hormon wanita), dan testosterone (Hormon pria). Itu paling signifikan fisik perubahan pubertas melibatkan peningkatan berurutan dalam Genital sistem dan karakteristik sekunder. Ini perubahan terjadi lebih periode 2 sampai 4 tahun dihasilkan di kecepatan tinggi puncak dan pertumbuhan rambut kemaluan. Wanita mulai untuk mengembangkan payudara (thelarche), tumbuh rambut ketiak, dan menstruasi. mengalami pertumbuhan laki-laki rambut kemaluan (pubarche), awal testis dan penis pertumbuhan, emisi nokturnal, ditandai perubahan suara, pertumbuhan rambut wajah, dan pengembangan otot. Bukan itu biasa bagi perempuan untuk menjadi lebih tinggi dan lebih berat dari anak laki-laki pada usia yang sama selama masa remaja awal. Otak Pertumbuhan dan Pembangunan Selain pertumbuhan fisik, adoles- muda persen mengalami CNS pematangan tanpa peningkatan ukuran otak. Perkembangan otak terdiri dari miliaran Sel-sel yang berada di tempat (dengan kehidupan janin akhir). Neurologis penghinaan pada awal masa remaja dapat

\footnotetext{
${ }^{23}$ Herman-Giddens, M. E., Slora, E. J., Wasserman, R. C., Bourdony, C. J., Bhapkar, M. V., Koch, G. G., \& Hasemeier, C. M. (1997). Secondary sexual characteristics and menses in young girls seen in office practice: A study from the Pediatric Research and Office Settings network. Pediatrics, 99, 505-512.
} 
memiliki samping utama berdampak pada paparan perkembangan selanjutnya terhadap infeksi dan racun. Selain itu, efek dari penghinaan ini ke otak dapat diamati pada remaja muda yang terkena infeksi dan racun yang merusak mereka otak dalam rahim. ancaman lain dari lingkungan yang dapat menyebabkan cedera otak yang cukup besar akibat dari paparan kekerasan, malnutrisi, kemiskinan, dan efek samping dari stres kronis. Beberapa ahli berpendapat bahwa para perkembangan periode penawaran awal masa remaja sebuah jendela dari kesempatan untuk memperbaiki kerusakan atau deficit dalam fungsi otak atau koneksi neurocortical. Mereka menawarkan bahwa itu otak remaja pada tahap ini pembangunan adalah diperbaiki dan mengatakan bahwa karena plastisitas dari otak tisu, sel-sel otak memiliki kemampuan yang luar biasa untuk beradaptasi dengan perubahan dan tantangan yang terjadi sepanjang kehidupan. Intervensi dirancang untuk merangsang berbagai fungsi otak dapat meningkatkan atau pengaruh itu keterkaitan selsel otak atau sirkuit otak. Seperti itu lingkungan stimulasi juga important Adolescence adalah masa transisi dari pertumbuhan, pengembangan, dan pematangan yang dimulai pada akhir dari masa kanak-kanak sekitar 10 tahun. (Neil J. Salkind. 2006) ${ }^{24}$

\section{Perubahan gonad Fungsi di Pubertas}

Perubahan dalam sistem reproduksi yang paling jelas ciri pubertas melibatkan pematangan gonad dan pengembangan berikutnya dari karakteristik seksual sekunder, yang dihasilkan dari peningkatan produksi hormon steroid gonad. Perempuan pematangan pubertas melibatkan amplifikasi proses pertumbuhan folikel ovarium dan steroidogenesis, yang terjadi sampai batas tertentu sebelum pubertas (Van Wagenen \& Simpson, 1973). ${ }^{25}$ Peningkatan produksi hormon steroid oleh ovarium merangsang proliferasi dinding rahim, dan penarikan dukungan steroid pada akhir setiap siklus mengarah ke menstruasi. Menstruasi pertama disebut sebagai menarche dan saya biasa digunakan sebagai penanda pubertas, meskipun itu adalah peristiwa yang relatif terlambat dalam kaskade kejadian yang menyebabkan pubertas pematangan sistem reproduksi. Peningkatan produksi steroid ovarium juga merangsang pembesaran payudara, pertumbuhan rambut kemaluan, dan deposisi lemak tubuh dalam pola perempuan yang khas. Pada akhirnya, pematangan pubertas ovarium mengarah ke pembentukan fungsi ovarium siklik, dengan ovulasi biasa. Umumnya siklus ovulasi pertama terjadi beberapa bulan setelah menarche, dan pembentukan siklus ovulasi

\footnotetext{
${ }^{24}$ Neil J. Salkind. 2006 , Encyclopedia of human development. the United States of America. Sage Publications, Inc. p. 28

${ }^{25}$ Van Wagenen, G., \& Simpson, M. E. (1973). Postnatal development of the ovary in Homo sapiens and Macaca mulatta. New Haven, CT: Yale University Press.
} 
berturut tidak terjadi selama berbulan-bulan untuk tahun setelah menarche (Rowell, $1977{ }^{26}$ Apter, Viinikka, \& Vihko, 1978). ${ }^{27}$

Pada pria, perkembangan pubertas testis memerlukan stimulasi sel Leydig untuk menghasilkan jumlah peningkatan testosteron, testic pertumbuhan ular yang dihasilkan dari proliferasi tubulus dan elemen seluler yang terlibat dalam produksi sperma, dan akhirnya produksi sperma matang (Van Wagenen \&: Simpson, 1954; ${ }^{28}$ Agustus, Grumbach, \&: Kaplan, 1972 ${ }^{29}$ Dang \& Meussy-Dessolle, 1984 ${ }^{30}$ ). Selain memainkan peran penting dalam pematangan testis dan produksi sperma, meningkatkan produksi hormon testis merangsang pertumbuhan genitalia eksterna laki-laki, menyebabkan pengembangan pola rambut maskulin (di daerah, termasuk pertumbuhan janggut dan kebotakan), dan mengarah ke peningkatan massa otot .

\section{Perubahan Gonadotropin Sekresi di Pubertas}

pematangan gonad pada laki-laki dan hasil betina dari peningkatan sekresi gonadotropin hipofisis anterior, LH dan FSH (Styne \& Grumbach, $1978 ;{ }^{31}$ Steiner \& Bremner, 198132; Tanaman, 1983) .Tidak hanya melakukan mean tingkat sirkulasi LH dan FSH meningkat, namun amplitude pulsa LH individu juga meningkatkan (BOYAR et al, 1974a; ${ }^{33}$ Steiner \& Bremner, 1981). Namun, penelitian pada manusia menunjukkan bahwa frekuensi LH pulsa mirip pada anak-anak sebelum pubertas dan dewasa (Penny, Olambiwonnu, \& Frasier, 1977; ${ }^{34}$ Jakacki et al, 1982) ${ }^{35}$. pematangan pubertas sekresi pulsatile gonadotropin dibedakan dengan pola yang sangat berbeda dari rilis LH, dengan ketinggian nokturnal amplitudo pulsa (Boya et al, 1974a; ${ }^{36}$ Beck \&

\footnotetext{
${ }^{26}$ Rowell, T. E. (1977). Variation in age at puberty in monkeys. Folia Primatologia, 27, 284-290.

${ }^{27}$ Apter, D., Viinikka, L., \& Vihko, R. (1978). Hormonal pattern of adolescent menstrual cycles. Journal of Clinical Endocrinology and Metabolism, 47, 944- 954.

${ }^{28}$ Van Wagenen, G., \& Simpson, M. E. (1954). Testicular development in the rhesus monkey. Anatomical Records, 118, $231-251$.

${ }^{29}$ August, G. P., Grumbach, M. M., \& Kaplan, S. L. (1972). Hormonal changes in puberty. III. Correlation of plasma testosterone,

LH, FSH, testicular size, and bone age with male pubertal development. Journal of Clinical Endocrinology and Metabolism, 34, 319 326.

${ }^{30}$ Dang, D. C., \& Meusy-Dessolle, N. (1984). Quantitative study of testis histology and plasma androgens At onset of

spermatogenesis in the prepubertal laboratory-born macaque(Macaca fascicularis). Archives Of Andrology, 12(Suvpl.), 43-51.

${ }^{31}$ Styne, D. M., \& Grumbach, M. M. (1978). Puberty in the male and female: Its physiology and disorders. In S. S. C. Yen \& R. B. Jaffe (Eds.), Reproduc live endocrinology, physiology, pathophysiology and clinical management (pp. 189-235). Philadelphia: Saunders.

${ }^{32}$ Steiner, R. A., \& Bremner, W. J. (1981). Endocrine correlates of sexual development in the male monkey, Macaca fascicularis. Endocrinology, 309, 914-918.

${ }^{33}$ Boyar, R. M., Rosenfeld, R. S., Kapen, S., Finkelstein, J. W., Roffwarg, H. P., Weitzman, E. D., \& Hellman, L. (1974a). Human puberty. Simultaneous augmented secretion of luteinizing hormone and testosterone during sleep. Journal of Clinical Investigation 54, 609-618.

${ }^{34}$ Penny, R., Olambiwonnu, N. O., \& Frasier, S. D. (1977). Episodic fluctuations of serum gonadotropins in pre- and postpubertal girls and boys. Journal of Clinical Endocrinology and Metabolism, 45, 307-311

${ }^{35}$ Jakacki, R. I., Kelch, R. P., Sauder, S. E., Lloyd, J. S., Hopwood, N. J., \& Marshall, J. C. (1982). Pulsatile secretion of luteinizing hormone in children. Journal of Clinical Endocrinology and Metabolism, 55, 453-458.

${ }^{36}$ Boyar, R. M., Rosenfeld, R. S., Kapen, S., Finkelstein, J. W., Roffwarg, H. P., Weitzman, E. D., \& Hellman, L. (1974a). Human puberty. Simultaneous augmented secretion of luteinizing hormone and testosterone during sleep. Journal of Clinical Investigation, 54, 609-618
} 
Wuttke, $1980^{37}$; Steiner \& Bremner, 1981). Pada manusia, amplifikasi nokturnal ini LH sekresi unik untuk pubertas dan tidak diamati selama masa kanak-kanak atau di orang dewasa yang matang (BOYAR et al., 1972) .Dalam rhesus dan cynomolgus monyet, amplifikasi nokturnal LH sekresi terus sepanjang masa dewasa (Steiner et al., 1980 ${ }^{38}$ Tanaman \& Zorub, 1982) .Dalam manusia, peningkatan malam di LH sekresi telah terbukti berhubungan dengan tidur (Kapen et al., 1974) ${ }^{39}$, dan mungkin mencerminkan peningkatan tidur terkait di GnRH sekresi. Menariknya, pola yang sama dari sekresi malam hari LH tinggi terlihat pada orang dewasa pulih dari anoreksia nervosa, gangguan kejiwaan di mana aktivitas sistem reproduksi regresi ke keadaan sebelum pubertas selama periode diri inflictedstarvation (Boyaret al., 1974a PIRKE et al ., 1979). Meskipun sifat mencolok dari pola perkembangan ini LH sekresi, tidak muncul untuk menjadi penting untuk pematangan gonad (Wildt, Marshall, \& Knobil, 1980) ${ }^{40}$, dan kami masih tidak mengerti korelasi, jika ada, antara pola perkembangan LH sekresi dan pemicu untuk peningkatan pubertas sekresi gonadotropin (Gambar. 1-2 dan 1-3).

Studi pada monyet mengebiri (Plant, 1985) ${ }^{41}$ dan manusia dengan disgenesis gonad (Conte, Grumbach, \& Kaplan, 1975 ${ }^{42}$; Levine, Loriaux, \& Cutler, 1983) ${ }^{43}$ telah menunjukkan bahwa peningkatan pubertas sekresi gonadotropin terjadi dengan atau tanpa gonad pada dasarnya waktu yang sama. Temuan ini menunjukkan bahwa waktu onset pubertas tidak tergantung pada kegiatan gonad.

Peningkatan pubertas sekresi gonadotropin tampaknya didorong oleh peningkatan GnRH sekresi. dukungan yang sangat baik untuk konsep ini berasal dari penelitian yang menunjukkan bahwa pemberian GnRH eksogen (di pulsa per jam) ke prapubertas monyet rhesus perempuan terangsang dewasa seperti siklus menstruasi (Wildt et al., 1980). Temuan ini dan penelitian serupa di kera jantan prapubertas, menunjukkan bahwa GnRH eksogen dapat memulai sekresi testosteron dini dan

\footnotetext{
${ }^{37}$ Beck, W., \& Wuttke, W. (1980). Diurnal variations of plasma luteinizing hormone, follicle-stimulating hormone, and prolactin in boys and girls from birth to puberty. Journal of Clinical Endocrinology and Metabolism, 50, 635- 639.

${ }^{38}$ Steiner, R. A., Peterson, A. P., Yu, J. Y. L., Conner, H., Gilbert, M., terPenning, B., \& Bremner, W.

J. (1980). Ultradian luteinizing hormone and testosterone rhythms in the adult male monkey, Macaca fasckularis. Endocrinology, 107, 1489-1493.

${ }^{39}$ Kapen, S., Boyar, R. M., Finkelstein, J. W., Hellman, L., \& Weitzman, E. D. (1974). Effect of sleep-wake cycle reversal on luteinizing hormone secretory pattern in puberty. Journal of Clinical Endocrinology And Metabolism, 39 ,293-299.

${ }^{40}$ Wildt, L., Marshall, G., \& Knobil, E. (1980). Experimental induction of puberty in the infantile female rhesus monkey. Science, 207, 1373-1375.

${ }^{41}$ Plant, T. M. (1985). A study of the role of the postnatal testes in determining the ontogeny of gonadotropin secretion in the male rhesus monkey (Macaca mulatta). Endocrinology, 116,1341-1350.

${ }^{42}$ Conte, F. A., Grumbach, M. M., \& Kaplan, S. L. (1975). A diphasic pattern of gonadotropin secretion in patients with the syndrome of gonadal dysgenesis. Journal of Clinical Endocrinology and Metabolism, 40, 670-674.

${ }^{43}$ Levine, R. J., Loriaux, D. L., \& Cutler, Jr., G. B. (1983). Developmental changes in neuroendocrine regulation of gonadotropin secretion in gonadal dysgenesis. Journal of Clinical Endocrinology and Metabolism,57,288-293.
} 
spennatogenesis (Marshall, Wickings, \& Nieschlag, 1985) ${ }^{44}$, jelas menunjukkan bahwa reproduktif ketenangan sebelum pubertas tidak karena keterbatasan dalam kapasitas fungsional dari hipofisis atau gonad, melainkan muncul akibat dari`sekresi Gn'RH tidak cukup. Dengan demikian jelas bahwa isu sentral dalam memahami physiologicalcontrol

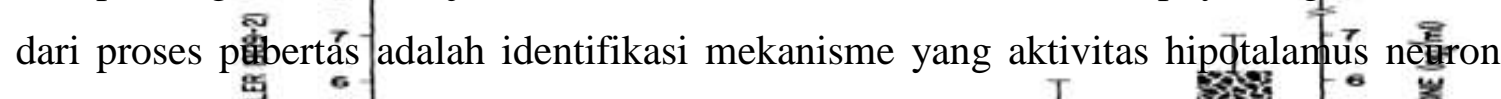
GnRH meningkat pada sabertas


Figure 1-2. Mean ( \pm SEM) serum LH and testosterone levels (top panel) measured in morming blood samples in groups of neonates, older infants, juveniles, peripubertals, and adult cynomolgus monkeys ( $)$, range of values ob served). (Bottom panel) Integrated (O-90 minutes) LH and testosterone responses to luteinizing hormone-releasing homone (LFRH) (5 $\mu$ g/kg, IV dose). (Taken from Steiner \& Bremner, 1981_)

${ }^{44}$ Marshall, G. R., Wickings, E. J., \& Nieschlag, E. (1985). Pulsatile GnRH administration in Immature male monkeys. Acta Endocrinologica, 108 (Suppl. 267), 179. 


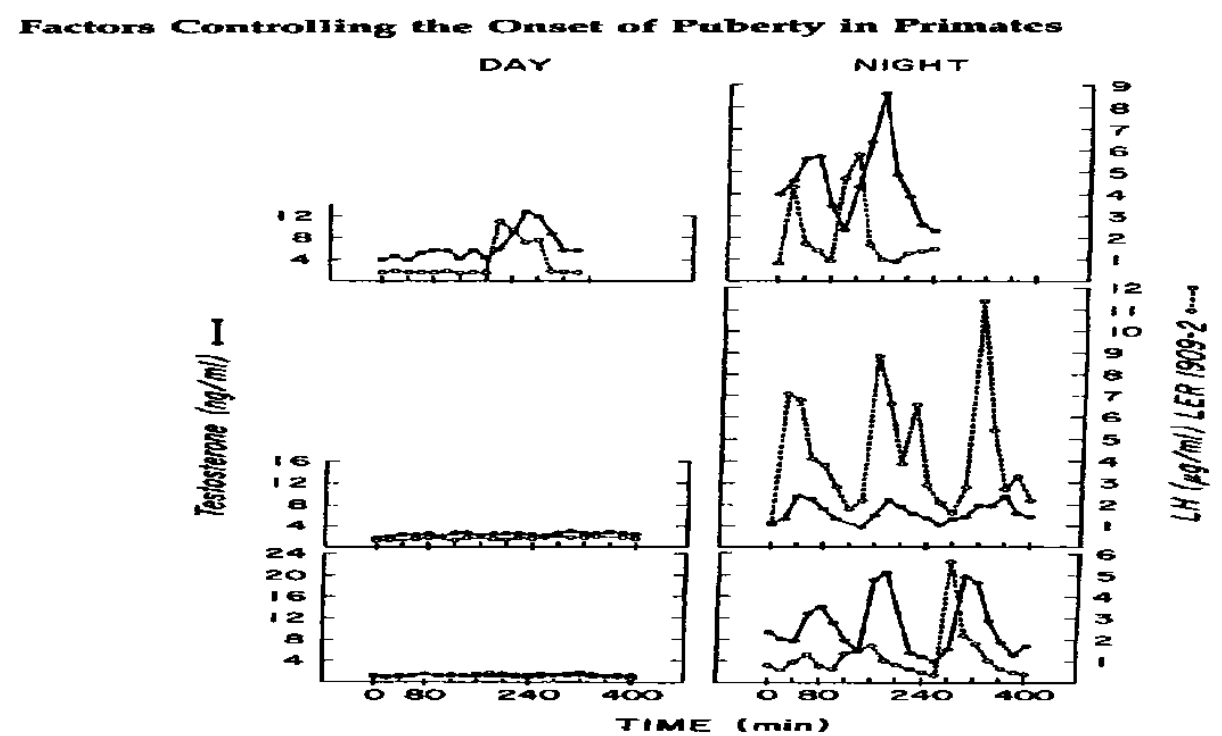

Figure 1-3. Relationship between TIME (min)

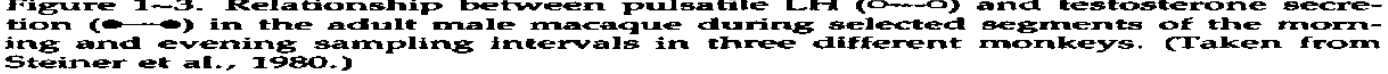

Dari perspektif endokrin, pubertas didefinisikan sebagai periode antara onset sekresi gonadotropin hipofisis dan pencapaian yang kompetensi reproduksi (fertilitas). efek belajar dari pubertas pada perilaku memerlukan pemeriksaan semua manifestasi pubertas termasuk perubahan morfologi (yaitu, pengembangan seks sekunder karakteristik), perubahan neuroendokrin, dan perubahan dalam sistem saraf modulasi sumbu endokrin Morfologi Pubertas Pubertas dikaitkan dengan dua perubahan fisik utama: peningkatan pertumbuhan somatik (yang pubertas "percepatan pertumbuhan") disertai dengan pematangan karakteristik seksual sekunder - rambut kemaluan, perkembangan alat kelamin, dan, pada anak perempuan, pertumbuhan payudara. Urutan sangat konsisten dalam penampilan fitur fisik memungkinkan penggunaan mereka sebagai penanda pematangan seksual. Disintesis penanda individu ke dalam tahap pematangan seksual ("Tanner tahap") yang memiliki sangat disederhanakan tujuan kuantifikasi dari proses kematangan seksual (Gambar 3.1). Pertumbuhan somatik mempercepat tak lama setelah timbulnya pematangan seksual. Re perbedaan merenung fl di usia sekresi steroid seks, yang percepatan pertumbuhan terjadi sebelumnya rata-rata pada anak perempuan (usia 10-12 tahun) dari anak laki-laki (usia 12-14 tahun). Pertumbuhan somatik mencakup peningkatan pesat dalam 


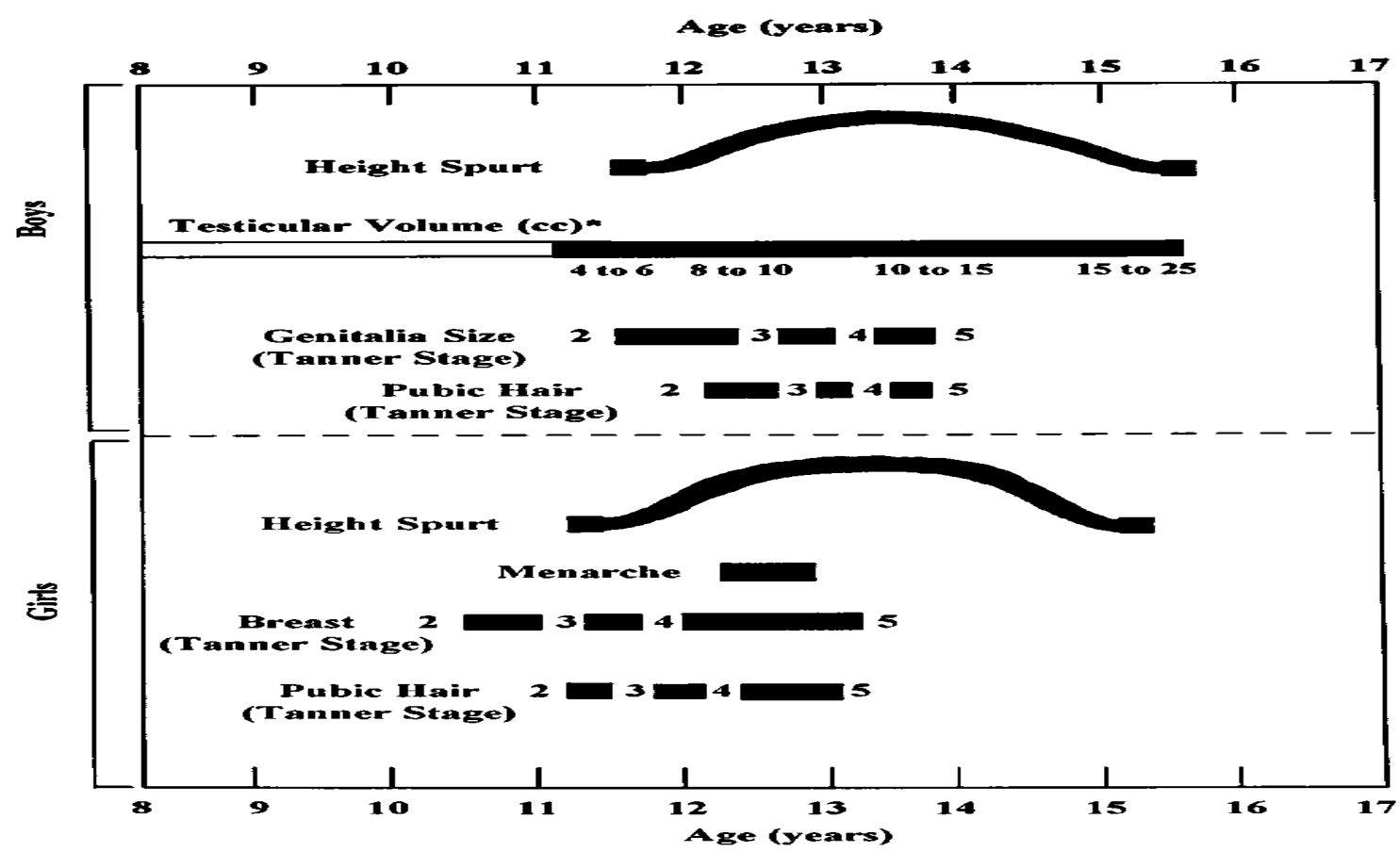

\section{Endokrin Perubahan}

Gambar 3.1. Urutan dari perubahan fisik pubertas, termasuk somatik pertumbuhan, pematangan kelamin, dan perkembangan karakteristik seksual sekunder, untuk anak laki-laki (panel atas) dan perempuan (panel bawah). Diadaptasi dari Wheeler, $1991 .^{45}$

\section{DAMPAK PSIKOLOGIS TERHADAP PERUBAHAN BENTUK FISIK}

Menurut Elizabeth B. Hurlock (1991) Ada beberapa dampak psikologis yang dialami remaja terhadap perubahan bentuk tubuh yang dialaminya terhadap sikap yang dilakoninya yakni, Penampilan yakni, perubahan perubahan yang meningkatkan penarnpilan diri seseorang akan diterima dengan senang hati dan mengarah sikap yang rnenvenangkan. sedangkan perubahan- perubahan yang mengurangi penampilan diri akan ditolak, dan segala cara akan · diusahakan untuk menutupinya. Perilaku, kalau perubahan-perubahan perilaku seperti yang terjadi selama masa puberitas dan usia lanjut, hal ini akan berpengaruh pada sikap terhadap perubahan-perubahan yang kurang menyenangkan. Hal sebaliknya terjadi kalau perubahan-perubahan yang menyenangkan, misalnya ketidak berdayaan masa bayi berkembang secara bertahap menuju kemandirian masa kanak-kanak. Stereotip Budaya, dari media massa, orang mempelajari stereotip budaya yang dikaitkan denqan berbagai usia. Dan stereotip ini dipakai untuk meenilai orang-orang dalam

Mary A. Carskadon. 2002. Adolescent Sleep Patterns, ( Biological, Social, and Psychological Influences). Cambridge University Press. New York. P. 29 
usia-usia tersebut. Nilai-nilai budaya setiap kebudayaan mempunyai nilai-nilai tertentu yang dikaitkan dengan usia-usia. yang berbeda. Karena produktivitas - maksimum di kaitkan dengan kemudaan dari usia muda hingga pertengahan dewasa dalam kebudayaan Amerika saat ini. maka sikap terhadap kelompok usia ini lebih menyenangkan ketimbang sikap terhadap terhadap usia terhadap usia-usia lainya. Perubahan Peranan, Sikap rerhadap orang dari bermacam-macam usia sangat dipengaruhi oleh peran yang mereka mainkan. Kalau orang mengubah peran mereka, mereka kurang senang, seperti pensiun atau menjanda, maka sikap masyarakat terhadap mereka kurang simpatik. Pengalaman Pribadi, yakni Pengalaman pribadi mempunvai pengaruh yang besar temadap sikap individu dalam rnenghadapi perubahan-perubahan yang terjadi dalam perkembangan karena kewenangan dan kewibawaan para eksekutif usia pertengahan. Menurun pada saat mereka menjelang pensiun. Sikap-sikap mereka terhadap ketuaan rnisalnya, menjadi kurang rnenyenangkan sikap-sikap ini sernakin dipertajam oleh sikap-sikap sosial yang kurang menyenangkan

\section{KENDALA PERKEMBANGAN FISIK}

Awal masa puber anak perempuan lebih rentan untuk masalah seperti merokok, minum,depresi, gangguan makan, diri negative, image, isolasi, perilaku patuh, dan kurang popularitas sedangkan untuk anak laki-laki, suara mulai menurunkan; kumis mulai tumbuh . anak laki-laki, yang melibatkan pematangan organ reproduksi dan menyertainya karakteristik seksual sekunder. Dalam perempuan, menstruasi pertama terjadi pada akhir masa pubertas. Pada akhir pubertas, individu menjadi mampu reproduksi. ${ }^{46}$ (The University of Pittsburgh. 2005) namun dalam proses perkembanganya biologis ada sebagaian remaja mengalami berbagai hambatan ataupun kendala diantaranya kekurangan hormon pertumbuhan sehingga dengan kurangnya jumlah hormon pertumbuhan pada akhir masa kanak-kanak dan awal masa puber menyebabkan anak menjadi lebih kecil dari rata-rata pada waktu ia matang. Kekurangan hormon gonad atau kalau hormon gonad tidak cukup banyak dikeluarkan atau dikeluarkan agak lambat untuk dapat mengawasi hormon pertumbuhan, maka pertumbuhan anggota badan berlangsung terlalu lama dan individu menjadi lebih besar dari rata-rata. Kurangnya jumlah hormon gonad juga mempengaruhi perkembangan normal organ-organ seks dan ciri-ciri seks sekunder sehingga individu tetap kekanak-

\footnotetext{
${ }^{46}$ (The University of Pittsburgh. 2005 Resource Book.Child and Adolescent Development. the Pennsylvania Child Welfare Training Program University of Pittsburgh, School of Social Work 403 East Winding Hill Road Mechanicsburg). p.54 
kanakan atau mengambil ciri-ciri lawan jenisbergantung pada kapan terjadinya gangguan dalam siklus perkembangan. Persediaan hormon gonad yang berlebihan juga menyebabkan ketidak seimbangan dalam berfungsinya kelenjar pituitary dan gonad menyebabkan produksi hormon gonad dalam jumlah yang berlebihan pada usia sangat muda yakni masa puber dialami lebih awal pada usia 5-6 tahun . ini dikenal sebagai masa puber yang terlalu awal atau puberity precox. Meskipun anak tersebut matang secara seksual dalam arti bahwa organ-organ seks sudah mulai berfungsi, tetapi bentuknya masih kecil dan ciri-ciri seks sekunder belum berkembang seperti anak yang matang pada usia yang normal. (Elizabeth. B. Hurlock. 1991) ${ }^{47}$

\section{BODY IMAGE REMAJA}

Monks (1999) ${ }^{48}$ membatasi usia remaja antara 12 hingga 21 tahun, yang terbagi dalam 3 fase, yaitu remaja awal (usia 12 hingga 15 tahun), remaja tengah/madya (usia 15 hingga 18 tahun) dan remaja akhir (usia 18 hingga 21 tahun). Masa remaja merupakan periode pematangan organ reproduksi manusia dan terjadi perkembangan identitas pribadi, sistem nilai moral , etika, perasaan harga diri dan pengembangan body image. Masa remaja terjadi pertumbuhan dan perkembangan secara dramatis dalam siklus kehidupan. Dampak psikologis yang dialami remaja terhadap perubahan bentuk tubuh berpengaruh terhadap sikap yang dilakoni remaja (Elizabeth B. Hurlock, 1991). Perubahan psikologis remaja menyebabkan remaja disibukan dengan tubuh mereka dan mengembangkan citra individual mengenai body image (Jhon W. Santrok, 2002). ${ }^{49}$

Menurut Aquino, Orense, Tanchoco, Amarra, Tajan, dan Cruz (2009) ${ }^{50}$, body image merupakan perasaan yang muncul pada diri seseorang terhadap penampilannya. Body image juga merupakan pandangan seseorang mengenai daya tarik tubuh yang dimiliki, penyimpangan ukuran tubuh, pandangan mengenai batasan- batasan tubuh, keakuratan persepsi mengenai perasaan jasmaniah/fisik (Schilder 1999 dan Fisher dalam Grogan, 1999. Thompson, J. Kevin, Heinberg, Leslie J., Altabe, Madeline \& TantleffDunn, Stacey, 2002) $)^{51}$

Grogran, (1999) ${ }^{52}$ membagi body image, ke dalam tiga aspek yaitu : 1. Persepsi (perceptions), meliputi penilaian terhadap ukuran tubuh yang dimiliki. Hal ini biasanya

\footnotetext{
${ }^{47}$ Op cit

${ }^{48}$ Monks, F. J. (1999). Psikologi perkembangan. Yogyakarta: Gadjah Mada. University Press.

${ }^{49}$ Op cit,

${ }^{50}$ Aquino, Mildred T., Orense, Consuelo L., Tanchoco, Celeste C., Amarra, Sofia V., Tajan, Merlyn G., \& Cruz, Evelyn O. Dela. (2009). Correlates of Body Image Satisfaction Among Economycally Depressed Urban Filipino Women. Philipine Journal of Science, (138 (1): 67-74)

${ }^{51}$ Thompson, J. Kevin, Heinberg, Leslie. J, Altabe, Madeline, \& Tantleff-Dunn, Stacey. (2002). Exacting Beauty. Washington: American Psychological Association.

${ }^{52}$ Grogan, Sarah. (1999). Body Image: Understanding Body Dissatisfaction in Men, Women, and Children. London: Routledge 
diikuti dengan membandingkan diri sendiri dengan orang lain (Gillen \& Lefkowits, $2011)^{53}$, 2. Pemikiran (thoughts), meliputi evaluasi terhadap daya tarik tubuh yang dimiliki. Setiap individu memiliki standar mengenai penampilan fisik dalam pikirannya, hal ini dapat mempengaruhi evaluasi mengenai tubuh yang dimiliki, sehingga evaluasi terhadap diri yang dihasilkan dapat berupa evaluasi positif dan evaluasi negatif (Heatherton, 1993). ${ }^{54}$ 3. Perasaan meliputi perasaan yang berhubungan dengan bentuk tubuh dan ukuran tubuh yang dimiliki. Perasaan yang muncul dapat berupa perasaan positif atau negatif dengan tubuh yang dimiliki. Para perempuan yang memiliki perasaaan negatif terhadap tubuhnya bisa menjadi stres dan cemas dengan tubuh yang dimiliki, bila bentuk dan ukuran tubuh mereka belum mencapai tubuh ideal (Devaraj \& Lewis, 2010). ${ }^{55}$ Cash (2003) menambahkan 2 hal yang berbeda dari pendapat Grogran $(1999)^{56}$ bahwa seseorang terkait dengan persepsi dan sikap diri terhadap tubuhnya bukan karena pemikiran dan perasaan saja namun juga disebabkan oleh 1.Kepercayaan meliputi cara pandang dan perasaan mengenai bentuk tubuhnya, sehingga lebih mudah beradaptasi dengan bentuk tubuhnya sendiri 2. Perilaku (behaviors), meliputi perilakuperilaku yang muncul dari perasaan dan pemikiran yang dimiliki oleh seseorang terhadap bentuk tubuhnya.

Body image akan perubahan pada bentuk tubuh dan ukuran tubuh menyebabkan banyak ambivalensi di kalangan remaja, yang mengarah ke pengembangan citra tubuh yang buruk (Brown, 2013) ${ }^{57}$. Jenis kelamin merupakan faktor yang mempengaruhi dalam perkembangan body Image seseorang (Dacey dan Kenny, 2001 ${ }^{58}$, Cash dan Pruzinsky, 2002) ${ }^{59}$. Jenis kelamin adalah faktor paling penting dalam perkembangan body image seseorang (Chase, 2001). ${ }^{60}$

Media yang muncul memberikan gambaran ideal mengenai figure perempuan dan laki-laki yang dapat mempengaruhi body image seseorang(Cash \& Purzinsky, 1990 dalam Lemberg \& Cohn, 1999) ${ }^{61}$. Konsep tubuh yang ideal pada perempuan adalah tubuh langsing (Sanggarwaty, 2003) ${ }^{62}$, sedangkan pada laki-laki adalah tubuh berisi,

\footnotetext{
${ }^{53}$ Gillen, Meghan M. \& Lefkowitz, Eva S. (2011). Body Size Perceptions in Racially/Ethnically. North American Journal of Psychology, (Vol. 13, No.3, 447-468).

${ }^{54}$ Heatherton, Todd F. (1993). Body Dissatisfaction, Self-Focus, And Dieting Status Among Women. Psychology of Addictive Behavior, (Vol. 7, No. 4, 225-231).

${ }^{55}$ Devaraj, Sowmya \& Lewis, Vivienne. (2010). Enhancing Positive Body Image in Women: An Evaluation of A Group Intervention Program. Journal of Applied Biobehavioral Research, (Vol. 15, No. 2, pp. 103-116)

${ }^{57}$ Brown, Judith E. Et.al. 2013. Nutrition Through the Life Cycle. Wadsworth: USA

${ }^{58}$ Dacey, J. \& Kenny, M. (2001). Adolescent development (2th ed). USA: Brown \& Benchmark Publishers.

${ }^{59}$ Cash, T. F. \& Pruzinsky, T. (2002). Body images: A handbook of theory, research, and clinical practice. Guilford Press

${ }^{60}$ Chase, M. E. (2001). Identity development and body image dissatisfaction in college females. New York: Guilford Publications.

${ }^{61}$ Lemberg, R., \& Cohn, L. (1999). Eating dirsorders: a reference sourcebook (2 ed.). Arizona: The Oryx Press

${ }^{62}$ Sanggarwaty, Ratih. (2003). Kiat menjadi model profesional. Jakarta: PT Gramedia Pustaka Utama 
berotot, berdada bidang, serta biseps yang menonjol (McCabe \& Ricciardeli, 2004) ${ }^{63}$. Kepedulian terhadap penampilan dan body image tubuh yang ideal dapat mengarah kepada upaya obsesif seperti mengontrol berat badan (Davison \& Birch dalam Papalia 2008) $)^{64}$. Hasil penelitian Pope, Philips, dan Olivardia (2000) ${ }^{65}$ menunjukkan bahwa perempuan lebih memperhatikan penampilan fisik dibandingkan laki-laki. Penjelasan ini bukan berarti penampilan fisik yang menarik hanya pada perempuan saja tetapi laki-laki pun terkadang memperhatikan penampilan mereka.

Casper dan Offer (1990) ${ }^{66}$ menyatakan kepuasan tumbuh berdasarkan jenis kelamin menunjukkan bahwa pada remaja laki-laki , kepuasan tubuh dikaitkan dengan fisik yang maskulin, Sedangkan bagi remaja perempuan, kepuasaan tubuh dikaitkan dengan berat badan. Dimensi ketidakpuasan tubuh berbeda untuk jenis kelamin (Franzoi \& Shield, 1984) ${ }^{67}$ remaja perempuan cenderung lebih puas dengan tubuh mereka khususnya dengan kaki, paha, dan pantat, dibandingkan dengan anak laki-laki (Siberstein, Striegel-Moore, Timko, \& Rodin, 1988) ${ }^{68}$. Namun apabila harapan tersebut tidak sesuai dengan kondisi tubuh aktualnya, maka hal ini dianggap sebagai body image yang negatif (Germov \& Williams, 2005) ${ }^{69}$.

Ketidakpuasan terhadap body image pada remaja perempuan umumnya mencerminkan keinginan untuk menjadi lebih langsing (Davison, Markey, \& Birch dalam Markey, 2005) ${ }^{70}$. Sedangkan pada remaja laki-laki ketidakpuasan terhadap tubuhnya juga timbul karena keinginan untuk menjadi lebih besar, lebih tinggi, dan berotot (Evans, 2008) ${ }^{71}$. Hal ini disebabkan karena adanya figur ideal yang menjadi panutan yang dapat diperoleh dari faktor luar seperti media. Media dapat mempengaruhi gambaran ideal akan sosok tubuh seseorang, baik itu laki-laki maupun perempuan. Semakin sering melihat sosok tubuh sempurna, maka semakin besar obsesi untuk bisa

\footnotetext{
${ }^{63}$ McCabe, M. P. (2004). A longitudinal study of pubertal timing and extreme body change behaviors among adolescent boys and girls. [on-line]. Available FTP:

${ }^{64}$ Papalia, D. E., Olds, S. W., \& Feldman, R. D. (2008). Human development (Psikologi perkembangan edisi kesembilan). Jakarta: Kencana.

${ }^{65}$ Pope, H.G., Phillips, K.A., \& Olivardia, R. (2000). The Adonis complex: The secret crisis of male body obsession. Sydney: The Free Press

${ }^{66}$ Casper, R. C., \& Offer, D. (1990). Weight and dieting concerns in adolescents, fashion or symptom? Pediatrics, 86, 384-390.B21

${ }^{67}$ Stephen L. Franzoi \& Stephanie A. Shields, (1984). The Body Esteem Scale: Multidimensional Structure and Sex Differences in a College Population. Journal of Personality Assessment. 48, 173-178

${ }^{68}$ Siberstein, L. R., Striegel-Moore, R. H., Timko, C., \& Rodin, J. (1988). Behavioural and psychological implications of body dissatisfaction: Do men and women differ? Sex Roles, 19, 219-232

${ }^{69}$ Germov J, Williams L. 2005. A Sociology of Food and Nutrition: The Social Appetite. Victoria: Oxford University Press

${ }^{70}$ Markey, Charlotte N. and Markey Patrick M. (2005). Relations between body image and dieting behaviors: An examination of gender differences. Journal of sex roles, vol. 53, vos. 7/8, October 2005 (C_ 2005)

${ }^{71}$ Evans, Retta R., Jane Roy, Brian G., Karen We., \& Donna B. (2008). Ecological strategies to promote healthy body image among children. The journal of school health, 78 (7), 359-367.
} 
seperti model dalam majalah (Harmatz, Gronendyke \& Thomas, dalam Mills \& D'Alfonso 2007) ${ }^{72}$.

Dorongan psikologis yang dialami remaja dapat mempengaruhi dalam menentukan pola makannya sehingga remaja menjadi sensitif tentang body image . Remaja obesitas sangat rentan terhadap diskriminasi sosial. Body image, dan gangguannya, adalah penentu penting dari praktek diet dan risiko gizi pada remaja, khususnya di kalangan perempuan (WHO, 2005) ${ }^{73}$. Pada Umumnya remaja melakukan diet, berolahraga, melakukan perawatan tubuh, mengkonsumsi obat pelangsing dan lainlain untuk mendapatkan berat badan yang ideal (Dacey \& Kenny, 2001) ${ }^{74}$. Hal ini dilakukan karena remaja menyadari bahwa mereka yang menarik biasanya mendapat perlakuan lebih baik dari pada mereka yang kurang menarik (Hurlock, 1999) ${ }^{75}$. Sedangkan persepsi negatif remaja terhadap body image akan menghambat perkembangan kemampuan interpersonal dan kemampuan membangun hubungan yang positif dengan remaja lain (Dacey dan Kenny, 2001) ${ }^{76}$

Berdasarkan pemaparan di atas, dapat disimpulkan bahwa perhatian terhadap gambaran tubuh sangat kuat terjadi pada masa remaja, baik pada remaja laki-laki maupun perempuan. Perasaan puas dan tidak puas terhadap fisik akan mempengaruhi penilaian, pemikiran, persepsi, kepercayaan dan perilaku remaja. Para remaja melakukan berbagai usaha agar mendapatkan gambaran tubuh yang ideal sehingga terlihat menarik dengan melakukan berbagai usaha.

\section{DAFTAR PUSTAKA}

Alsaker, F. D. (1992). Pubertal timing, overweight and psychological adjustment. Journal of Early Adolescence, 12, 396-419.

Apter, D., Viinikka, L., \& Vihko, R. (1978). Hormonal pattern of adolescent menstrual cycles. Journal of Clinical Endocrinology and Metabolism, 47, 944954.

Aquino, Mildred T., Orense, Consuelo L., Tanchoco, Celeste C., Amarra, Sofia V., Tajan, Merlyn G., \& Cruz, Evelyn O. Dela. (2009). Correlates of Body Image Satisfaction Among Economycally Depressed Urban Filipino Women. Philipine Journal of Science, (138 (1): 67-74)

\footnotetext{
${ }^{72}$ Mills, J. S., \& D’Alfonso, S. R. (2007). Competition and male of body image: Increased drive for muscularity following failure to female. Journal of social and clinical psychology, 26(4), 505-519

${ }^{73}$ WHO. 2005. Nutritional in adolescence - Issues and Challanges for Health Sector.Geneva 2005

${ }^{74}$ Dacey, J. \& Kenny, M. (2001). Adolescent development (2th ed). USA: Brown \& Benchmark Publishers

${ }^{75}$ Hurlock. B. E. (1999). Psikologi perkembangan: Suatu pendekatan sepanjang rentang kehidupan (edisi kelima). Jakarta: Penerbit Erlangga

${ }^{76}$ Dacey, J. \& Kenny, M. (2001). Adolescent development (2th ed). USA: Brown \& Benchmark Publishers 
August, G. P., Grumbach, M. M., \& Kaplan, S. L. (1972). Hormonal changes in puberty. III. Correlation of plasma testosterone, LH, FSH, testicular size, and bone age with male pubertal development. Journal of Clinical Endocrinology and Metabolism, 34, 319-326.

Beck, W., \& Wuttke, W. (1980). Diurnal variations of plasma luteinizing hormone, follicle-stimulating hormone, and prolactin in boys and girls from birth to puberty. Journal of Clinical Endocrinology and Metabolism, 50, 635- 639.

Boyar, R. M., Rosenfeld, R. S., Kapen, S., Finkelstein, J. W., Roffwarg, H. P., Weitzman, E. D., \& Hellman, L. (1974a). Human puberty. Simultaneous augmented secretion of luteinizing hormone and testosterone during sleep. Journal of Clinical Investigation, 54, 09-618.

Brown, Judith E. Et.al. 2013. Nutrition Through the Life Cycle. Wadsworth: USA

Cash, T. F. \& Pruzinsky, T. (2002). Body images: A handbook of theory, research, and clinical practice. Guilford Press

Casper, R. C., \& Offer, D. (1990). Weight and dieting concerns in adolescents, fashion or symptom? Pediatrics , 86, 384-390.B21

Chase, M. E. (2001). Identity development and body image dissatisfaction in college females. New York: Guilford Publications.

Conte, F. A., Grumbach, M. M., \& Kaplan, S. L. (1975). A diphasic pattern of gonadotropin secretion in patients with the syndrome of gonadal dysgenesis. Journal of Clinical Endocrinology and Metabolism, 40, 670-674.

Dacey, J. \& Kenny, M. (2001). Adolescent development (2th ed). USA: Brown \& Benchmark Publishers

Dang, D. C., \& Meusy-Dessolle, N. (1984). Quantitative study of testis histology and plasma androgens At onset of spermatogenesis in the prepubertal laboratoryborn macaque(Macaca fascicularis). Archives Of Andrology, 12(Suvpl.), 4351.

Devaraj, Sowmya \& Lewis, Vivienne. (2010). Enhancing Positive Body Image in Women: An Evaluation of A Group Intervention Program. Journal of Applied Biobehavioral Research, (Vol. 15, No. 2, pp. 103-116)

Elizabeth B Hurlock. 1980. Developmental Psychology. A life-span approach, fifth edition. McGraw-Hill. Inc. pp. 206

Evans, Retta R., Jane Roy, Brian G., Karen We., \& Donna B. (2008). Ecological strategies to promote healthy body image among children. The journal of school health, 78 (7), 359-367.

Germov J, Williams L. 2005. A Sociology of Food and Nutrition: The Social Appetite. Victoria: Oxford University Press

Gillen, Meghan M. \& Lefkowitz, Eva S. (2011). Body Size Perceptions in 
Racially/Ethnically. North American Journal of Psychology, (Vol. 13, No.3, 447-468).

Grogan, Sarah. (1999). Body Image: Understanding Body Dissatisfaction in Men, Women, and Children. London: Routledge

Heatherton, Todd F. (1993). Body Dissatisfaction, Self-Focus, And Dieting Status Among Women. Psychology of Addictive Behavior, (Vol. 7, No. 4, 225-231).

Herman-Giddens, M. E., Slora, E. J., Wasserman, R. C., Bourdony, C. J., Bhapkar, M. V., Koch, G. G., \& Hasemeier, C. M. (1997). Secondary sexual characteristics and menses in young girls seen in office practice: A study from the Pediatric Research and Office ttings network. Pediatrics, 99, 505-512.

Hurlock. B. E. (1999). Psikologi perkembangan: Suatu pendekatan sepanjang rentang kehidupan (edisi kelima). Jakarta: Penerbit Erlangga

J. (1980). Ultradian luteinizing hormone and testosterone rhythms in the adult male monkey, Macaca fasckularis. Endocrinology, 107, 1489-1493.

Joanne M. Williams, Candace Currie. Self-Esteem and Physical Development in Early Adolescence: Pubertal Timing and Body Image. University of Edinburgh. Journal of Early Adolescence, Vol. 20 No. 2, May 2000 129-149

Jakacki, R. I., Kelch, R. P., Sauder, S. E., Lloyd, J. S., Hopwood, N. J., \& Marshall, J. C. (1982). Pulsatile secretion of luteinizing hormone in children. Journal of Clinical Endocrinology and Metabolism, 55, 453-458.

John Bancrof dan June Machover Reinisch (1990). Adolesence and puberity. New York Oxford Oxford University Press

Kapen, S., Boyar, R. M., Finkelstein, J. W., Hellman, L., \& Weitzman, E. D. (1974). Effect of sleep-wake cycle reversal on luteinizing hormone secretory pattern in puberty. Journal of Clinical Endocrinology And Metabolism, 39 ,293-299.

Lamb, C. S., Jackson, L., Cassidy, P., \& Priest, D. (1993). Body figure preferences of men and women: A comparison of two generations. Gender Roles, 28, 345358.

Lemberg, R., \& Cohn, L. (1999). Eating dirsorders: a reference sourcebook (2 ed.). Arizona: The Oryx Press

Levine, R. J., Loriaux, D. L., \& Cutler, Jr., G. B. (1983). Developmental changes in neuroendocrine regulation of gonadotropin secretion in gonadal dysgenesis. Journal of Clinical Endocrinology and Metabolism,57,288-293.

Mary A. Carskadon. 2002. Adolescent Sleep Patterns, ( Biological, Social, and Psychological Influences). Cambridge University Press. New York. P. 29

Markey, Charlotte N. and Markey Patrick M. (2005). Relations between body image and dieting behaviors: An examination of gender differences. Journal of sex roles, vol. 53, vos. 7/8, October 2005 (C_ 2005) 
Marshall, G. R., Wickings, E. J., \& Nieschlag, E. (1985). Pulsatile GnRH administration in Immature male monkeys. Acta Endocrinologica, 108 (Suppl. 267), 179.

McCabe, M. P. (2004). A longitudinal study of pubertal timing and extreme body change behaviors among adolescent boys and girls. [on-line]. Available FTP:

Mills, J. S., \& D'Alfonso, S. R. (2007). Competition and male of body image: Increased drive for muscularity following failure to female. Journal of social and clinical psychology, 26(4), 505-519

Monks, F. J. (1999). Psikologi perkembangan. Yogyakarta: Gadjah Mada. University Press.

National Research Council, Board on Children, Youth, and Families. (1999). Adolescentdevelopment and the biology of puberty. Washington:National Academy Press. p. 1

Neil J. Salkind. 2006 , Encyclopedia of human development. the United States of America. Sage Publications, Inc. p. 28

Papalia, D. E., Olds, S. W., \& Feldman, R. D. (2008). Human development (Psikologi perkembangan edisi kesembilan). Jakarta: Kencana.

Penny, R., Olambiwonnu, N. O., \& Frasier, S. D. (1977). Episodic fluctuations of serum gonadotropins in pre- and postpubertal girls and boys. Journal of Clinical Endocrinology and Metabolism, 45, 307-311

Piaget, J.1969. The Intellectual development of the adolescence: Psychosocial perspectives, New York: Basic Books. p.22-26)

Plant, T. M. (1985). A study of the role of the postnatal testes in determining the ontogeny of gonadotropin secretion in the male rhesus monkey (Macaca mulatta). Endocrinology, 116,1341-1350.

Pope, H.G., Phillips, K.A., \& Olivardia, R. (2000). The Adonis complex: The secret crisis of male body obsession. Sydney: The Free Press

Resource Book. 2005 Child and Adolescent Development. the Pennsylvania Child Welfare Training Program University of Pittsburgh, School of Social Work 403 East Winding Hill Road Mechanicsburg). p.54

Richard M. Lerner, M. Ann Easterbrooks, Jayanthi Mistry. (2003) Handbook Of Psychology. Volume 6 Developmental Psychology. By John Wiley \& Sons, Inc., Hoboken, New Jersey.. P. 299

Rowell, T. E. (1977). Variation in age at puberty in monkeys. Folia Primatologia, 27, 284-290.

Sanggarwaty, Ratih. (2003). Kiat menjadi model profesional. Jakarta: PT Gramedia 


\section{Pustaka Utama}

Santrock John W.1983. Life-Span Development : 5 E. University of Texas At Dallas.

C. Brown Communication, Inc.) p. 7

Siberstein, L. R., Striegel-Moore, R. H., Timko, C., \& Rodin, J. (1988). Behavioural and psychological implications of body dissatisfaction: Do men and women differ? Sex Roles, 19, 219-232

Stattin, H., \&Magnusson, D. (1990). Pubertal maturation in female development. Hillsdale, NJ: Lawrence Erlbaum.

Steiner, R. A., \& Bremner, W. J. (1981). Endocrine correlates of sexual development in the male monkey, Macaca fascicularis. Endocrinology, 309, 914-918.

Steiner, R. A., \& Cameron, J. L. (1989). Endocrine control of reproduction. In B. Hille, A. Fuchs, R. Steiner, \& A. Scher (Eds.), Textbook of physiology (pp 1289-1342). Philadelphia: Saunders.

Steiner, R. A., Peterson, A. P., Yu, J. Y. L., Conner, H., Gilbert, M., terPenning, B., \& Bremner, W.

Stephen L. Franzoi \& Stephanie A. Shields, (1984). The Body Esteem Scale: Multidimensional Structure and Sex Differences in a College Population. Journal of Personality Assessment. 48, 173-178

Styne, D. M., \& Grumbach, M. M. (1978). Puberty in the male and female: Its physiology and disorders. In S. S. C. Yen \& R. B. Jaffe (Eds.), Reproduc live endocrinology, physiology, pathophysiology and clinical management (pp. 189-235). Philadelphia: Saunders.

Terasawa, E., Noonan, J. J., Nass, T. E., \& Loose, M. D. (1984). Posterior hypothalamic lesions advance the onset of puberty in the female rhesus monkey. Endocrinology, 115, 2241-2250.

The University of Pittsburgh. 2005 Resource Book.Child and Adolescent Development. the Pennsylvania Child Welfare Training Program University of Pittsburgh, School of Social Work 403 East Winding Hill Road Mechanicsburg). p.54+B23

Thompson, J. Kevin, Heinberg, Leslie. J, Altabe, Madeline, \& Tantleff-Dunn, Stacey. (2002). Exacting Beauty. Washington: American Psychological Association.

Van Wagenen, G., \& Simpson, M. E. (1954). Testicular development in the rhesus monkey. Anatomical Records, 118, 231-251.

WHO. 2005. Nutritional in adolescence - Issues and Challanges for Health Sector.Geneva 2005

Wildt, L., Marshall, G., \& Knobil, E. (1980). Experimental induction of puberty in the infantile female rhesus monkey. Science, 207, 1373-1375 
